\title{
Change of Function and Role of Coastal Women in Biangkeke Village Regency of Bantaeng
}

\author{
Hamka Naping $^{1 \mathrm{a}}$; Safriadi ${ }^{1}$; Icha Musywirah ${ }^{1}$ \\ ${ }^{1}$ Department of Anthropology, Hasanuddin University, Makassar, Indoneisa \\ ${ }^{a}$ Corresponding author: hamka_naping@yahoo.com
}

\begin{abstract}
The phenomenon of shifting the functions and roles of women from the domestic sector to the public sector is a logical consequence of the development of science and technology, as well as the growing ideology of capitalism and liberalism up to the countryside. The fishermen in the formerly isolated and subsistence village of Biangkeke experienced significant social, economic, cultural and technological changes, so that they have become an open society and accept various elements of cultural values coming from outside. The entry of seaweed cultivation becomes the determinant for the change of function and the role of women. The focus of this study is the form of function and the ideal role of women according to local culture concept, and how the form and process change the function and role of coastal women after engaging in the management of seaweed cultivation, what is the impact of changes to the socio-economic life of the community. Using a qualitative approach by relying on in-depth interviews and observations involved as a data collection strategy. Data obtained from informants consisting of; women who have worked as seaweed managers for about five years, community leaders and government leaders who understand the issues studied. The analysis is done by sorting and integrating data to form the basis for the description and formulating meaningful statements that are then thickened into theoretical propositions and conclusions. The study found, firstly, that the change of function and role of coastal women in seaweed farming communities in Biangkeke village is related to the change of function from only managing the household affairs, to the functions and roles involved in seaweed farming. The process of change begins with the introduction of seaweed cultivation, then gradually the women involve themselves in the processing of seaweed cultivation. As a result of changes in the function and role of women in the village of Biangkeke is an increase in living standards and community welfare.
\end{abstract}

Keywords-houshold, status and role change, coastal women, seaweed

\section{INTRODUCTION}

Almost all studies of the existence of women in South Sulawesi, found that in the Bugis Makassar cultural values system men and women have different meanings and positions. Because of that difference, then in the life of Bugis Makassar people are discriminated against the treatment, rights and obligations, functions and roles between women and men [5]. Women's and men's social functions and roles are intentionally created differently, men are associated with functions and duties outside the home, whereas women who are destined to give birth and breast-feeding, take care of and do all things related to domestic affairs. Men are given the duties and responsibilities of earning a living, while the women take care of the household.

Abdullah emphasized the difference between men and women. Abdullah States: biological differences are considered as commonplace. the inequality that gave rise to the subordination of women was seen as commonplace, occurring within the family and in public life. The existence of the nature and culture diotomy embraced by the community reinforces the existence of segregation and separation between women and men. Men are regarded as the culture of women conquerors who are representative of nature or nature [1]

The difference between men and women also applies universally to the various cultures of the world, for example, by western societies in the past, likening and giving women a predicate according to duties and responsibilities such as taking care of children, clothing, kitchens and food [6]. While the culture and customs of the Bugis Makassar community in South Sulawesi emphasizes domestic work is the most basic task of women [5]. For the Bugis and Makassarese in South Sulawesi, women occupy important and honorable positions in the family, becoming symbols and pride, especially if they show ideal behavior according to their cultural expectations [5].

Empirically, the conditions and ideal position of Bugis Makassar women as described above, are gradually experiencing a shift. Currently women are starting to enter the public sphere in accordance with social structure changes that occur in society. Social change is defined as a process of community transformation that occurs because of the power and social interaction, whether desired or not [4]. Social change leads to changes in the structural level of society, which has implications for changes in the way household life, including the status and role of women.

\section{PRoBlem StATEMENT}

To know the various phenomena related to women's action in the public sector as a consequence of the change of function and the role of women in the economic structure of household economics, then conducted a search on the ground with based on a number of research questions as follows: a. What is the ideal role of women according to the local cultural value system, b. How does the process of changing the function and role of women from home activities become involved in seaweed cultivation activities, c. What is the impact of such 
changes for the welfare of coastal communities in Biangkeke Village, Bantaeng District.

\section{AIM OF RESEARCH}

This study aims to explain the function and role of women according to local cultural concept in Biangkeke village, the process of change of function and role of woman in seaweed cultivation activity, and the effect of change of function and role of woman to economy of coastal community in Biangkeke Village of Bantaeng Regency. The benefits of this research are, firstly for the dynamics and development of the field of anthropology science in South Sulawesi, especially related to the development of ethnographic-oriented approach application and approach. Second, a reference for local governments in formulating policies, especially those related to the strategy of seaweed cultivation development and efforts to manage and direct the changes that occur so as not to negatively impact the development of community life in the future.

\section{RESEARCH METHOD}

Anthropological research is a type of ethnographic research with a qualitative approach that is both emic and inductive. The research was conducted in Biangkeke village of Bantaeng Regency, South Sulawesi. Implementation of research in April 2017 to September 2017. Informants in the study consisted of; women involved in seaweed farming activities, community leaders, village level government, and seaweed farmers. Data collection techniques were conducted with in-depth interviews and participant observation, supported by literature review techniques. Informants are deliberately determined (purposive) by considering the ability to provide answers and descriptions of the problems studied. Data are analyzed by sorting and integrating data to form the basis for the formulation of meaningful statements which are then thickened into a number of theoretical propositions and conclusions.

\section{LITERATURE REVIEW}

\section{A. Status and Role of Women}

Sociologically and anthropologically, the concept of role and status are two important aspects of social relations. Roles are individual behavior in the social structure, and the dynamic aspect of the position which will provide certain facilities according to the role. Status indicates the position of the individual in society. In other words, the status gives someone a role as a pattern of interaction in socializing (social). A person is considered to have played a role if he has exercised rights and obligations in accordance with his status. The role a person gains by status. Marriage is a social contract between men and women to live together that is legalized by adat and religion as well as the state as a social process to obtain status [7]. By marriage, men and women automatically gain a new status that affects their role. Men will become husbands and father when they have children. Women will be wives and mothers for their children.

Double role gives women positions in two worlds of life (domestic role and public role) namely; The role of egalitarian, public activity takes more time and attention of women.
Nevertheless, the role of tradition is still taken into account, and contemporary Roles are the impact of women's choice to be independent. The number of these groups has not been much, but the clash of male dominance (which is not necessarily concerned with the interests of women) will increase the population [3].

\section{B. Duel Women Role}

The changing role and function of women provides equal opportunities for women and men in accessing themselves in areas such as education, health, employment and politics. This kind of situation because men start to give commitment to cooperation of woman. This is also caused by the commitment of men to provide opportunities for women or their wives to be active in social activities [4].

Although the changing times have taken place, the concept of gender justice is still difficult to realize. There is still a perception that men are better able to do more work than women. Men are "the first sex" while women are servants. It is these kinds of understandings that make the position of women not recognized in the household and at work (public).

\section{RESUlT AND DISCUSSION}

\section{A. Ideal Form of Role and Function of Women in Biangkeke Village}

The role of women and their status will be related to family and society. In the context of the community in Biangkeke Village, it is commonly known that the three roles of women, firstly, women as Indo ana, are the mother of her child who is in charge of caring for the child. Second, Women as Pattaro Pappole Asalawanggeng the woman acts as a keeper and sustenance provided by her husband. Third, women as repo 'Riatutui siri'na ie women play a role in maintaining the shame and honor of the family [2]. Women's important role in the household can not be underestimated. The work of taking care of the home and educating the child is an easy task. The burden of liability afforded to the enormous women resulted in women being protected from things that were deemed to undermine the honor of the family.

In the past few decades, if a woman in Biangkeke Village working in the public sector would be a source of shame for the family. Families especially husbands feel not dignified because they are considered unable to provide for their families. The implication is that the value of women is only seen from its role in the domestic sector. Any decision issued by women is not able to contribute greatly. As a result, women's dependence on men is very high.

However, at the moment, the role and status of women has changed. People's mindset also changed, many husbands allow their wives to be involved in the public sector, provided that the woman does not neglect the role of managing household activities. This is the beginning of women's dual role in life. It then spawned new roles for a woman. In the development of the image and prospects of the twenty-first century women, there are several roles performed by women, such as: The role of tradition, which puts women in the reproductive function, $100 \%$ of their lives are used for family care. In this role women 
are in the domestic sector and men in the public sector. The role of transition means that women have been involved in the public sector, although they still prioritize the role of tradition.

The development of science and technology led to changes in sociocultural structure of society in Boiangkeke Village. These changes have implications for the division of labor between men and women. The existence of women to meet the needs of the household economy becomes very meaningful. However, it does not mean that the public sector is the responsibility of women, but rather as a party that helps to fulfill the economic needs of the household. Meanwhile, the responsibility of fulfilling all the needs of the absolute household is the responsibility of the men or husbands. If women decide to help fulfill the family's economic needs, women are required not to forget their responsibilities in the domestic sector.

Women's presence in the public sector has gained recognition. Previously the duties and responsibilities of women only in the house, now women appear to show the potential and ability possessed by working in seaweed management activities. This change resulted in the role and status of women in the increasingly complex Biangkeke Village. In managing the household, women are required to control the domestic sector well. Jobs such as taking care of the needs of husbands and children and being educators who devote love to their children should not be overlooked.

\section{B. The Process of Changing Women's Roles and Functions in Biangkeke Village}

Starting from the cultivation of seaweed as one of the livelihoods of the Biangkeke people replacing old jobs as fishermen, women began to experience changes in roles and functions in their household economic structures. In the past, their husbands or fathers who worked as fishermen only played a role and functioned to manage and control household-related work such as cooking, washing clothes, cleaning and tidying homes, serving husbands, giving birth and raising their children. The additional work required is to prepare for the needs of the father or husband when they are going to catch fish in the sea, or sometimes they are asked by their husbands or fathers to help repair fishing gear such as trawled or damaged nets.

In the past women in the village of Biangkeke spent time with domestic activities such as talking to each other in the same way women discussed things that were actual and important to them, such activities were usually done in certain places such as around the well while washing clothes, or under the house while pounding rice, or perhaps at places where there is a wedding party or other celebration party which is usually attended by many women.

\section{CONCLUSION}

The ideal form of women's role according to the local cultural value system of the Biangkeke Village community is as a keeper of dignity and family gensi where the ideal woman is a woman who consistently maintains her dignity and dignity through a useful existence in the domestic sector. The process of changing the functions and roles of women is preceded by the entry and recognition of seaweed cultivation activities, which then continues until now women in Desaa Biangkeke are also involved in other activities in the public sector. The impact of the change of function and the role of women for the welfare of coastal communities in Biangkeke Village of Bantaeng Regency is very significant whose indicators can be seen in increasing income, fulfilling the needs of both primary and secondary.

\section{REFERENCES}

[1] I. Abdullah, Sangkan Paran Gender. Pusat Penelitian Kependuduka Universitas Gajah Mada. Yogyakarta. 2006.

[2] A.B. Hasan, Dinamika Eksistensi Perempuan. toACCAe. Makassar. 2005.

[3] E.L. Hastuti, Pemberdayaan Petani dan Kelembagaan Lokal dalam Perspektif Gender. Working Paper. No.50 Pusat Penelitian Sosial Ekonomi Pertanian. Bogor. 2004.

[4] G.K.R. Hemas, Wanita Indonesia Suatu Konsepsi Dan Obsesi. Liberty. Yogyakarta. 1992.

[5] Mattulada, Latoa. Hasanuddin University press. Makassar. 1995.

[6] H. Notopuro, Peranan Wanita Dalam Masa Pembangunan Indonesia. Penerbil GI. Jakarta. 1990.

[7] S. Pujileksono, Petualangan Antropologi. Malang: UMM press. 2006. 